\title{
Immune Function in Dairy Cows Related to Energy Balance and Metabolic Status in Early Lactation
}

\author{
By E Ropstad, H. J. Larsen and A. O. Refsdal
}

Department of Reproductive Physiology and Pathology, Department of Microbiology and Immunology, Norwegian College of Veterınary Medicine, Oslo, and Norwegian Red Cattle Associatıon, Hamar.

\begin{abstract}
Ropstad, E., H. J. Larsen and A. O. Refsdal: Immune function in dairy cows related to energy balance and metabolic status in early lactation. Acta vet. scand. 1989, 30, 209-219. - Two feedıng experıments were carried out in 2 successive years with 28 cows of the Norwegian Red Cattle (NRF) in each experiment.

The cows were randomly distributed into 4 groups and subjected to different feeding regimens from 1 month prior to calving until 12 weeks after calving. The experimental design was factorial $(2 \times 2)$ with respect to protein content of the concentrate $(17.5 \%$ digestible crude protein (DCP) v.s. $12.5 \%$ DCP) and concentrate allowances (standard v.s. substandard allowances after calving). Silage was offered ad libitum.

Samples for estımation of serum immunoglobulin-G, white blood cells and lymphocyte responses to the mitogens phytohemagglutinin, concanavalin A and pokeweed mitogen were collected 4 weeks prior to expected calving, and 2, 4 and 8 weeks after calving. The levels of milk immunoglobulin-G were estimated at calving and 2, 4 and 8 weeks after calving.

A significant positive relationship was found between the estimated energy balance and the lymphocyte response to mitogens. Little evidence was found for the existence of a significant relationsip between the immunologic parameters and plasma indicators of metabolic status. The lymphocyte response to phytohemagglutinin and levels of serum immunoglobulin-G increased, while levels of milk immunoglobulın-G decreased during the period from calving to 8 weeks after calving.

Increased milk somatic cell counts were associated with a significant decrease in the lymphocyte responses to mitogens.
\end{abstract}

phytohemagglutinın; pokeweed mıtogen; concanavalin-A; immunoglobulin-G; white blood cells; ketosis;liver function; plasma constituents; nutrition; underfeeding.

\section{Introduction}

In dairy cows in early lactation, the demand of the mammary gland for glucose often exceeds the amount of glucose available. This imbalance leads to negative energy and carbohydrate balance, increased fat mobilization and increased hepatic ketogenesis, thus rendering the cows more susceptible to ketosis. As reported earlier (Saarinen \& Shaw 1950, Gröhn et al. 1983) a fatty liver is a common finding in cases of ketosis.

In humans, there is considerable evidence that severe undernutrition is associated with an impairment of immune functions 
(Chandra \& Chandra 1986). Only little information is available in the literature concerning the relationship between metabolic status and immune function in dairy cows. According to Targowski \& Klucınski (1983), the mitogenic response to phytohemagglutinin was reduced when bovine lymphocytes were preincubated with $\beta$-hydroxybutyrate or acetoacetate. Reid et al. (1983) reported that high liver fat content in dairy cows was associated with reduction in the number of peripheral white blood cells. A tendency was also observed for cows with a high liver fat content to show lower milk somatic cell counts.

Irrespective of metabolic condition, a marked maternal immunosuppression has been reported to arise in several species during pregnancy, especially around the time of parturition (Wells et al. 1977, Burrels et al. 1978, Yamamoto et al. 1980, Lloyd et al. 1983). This immunosuppression is directed not only against foetal antigens, but extends non-specifically to affect a variety of unrelated immunological responses altering the host's responsiveness to infection by bacteria, viruses, protozoa and helminths (Lloyd 1983).

Taking the stage of lactation into account, the purpose of this study was to evaluate the possible influences of metabolic status and liver function on non-specific immune function in dairy cows. Another aim was to assess possible relationships between udder health and immune function.

\section{Materials and methods}

\section{Animals and experimental design}

Two feeding experiments were carried out in 2 successive years with 28 cows of the Norwegian Red Cattle (NRF) in each experiment. Taking the date of calving into account, the cows were randomly distributed into 4 groups which were subjected to diffe- rent feeding regimens during the period of 1 month prior to calving to 12 weeks after calving. Primiparous cows totalled 8 in year 1 and 7 in year 2, respectively, and were, as far as possible, evenly distributed among the feeding groups.

The experimental design was factorial $(2 \times 2)$ with respect to protein content of the concentrates fed, and concentrate allowances after calving.

Two high-protein groups $(\mathrm{Hp})$ received concentrates with $17.5 \%$ digestible crude protein (DCP) either in substandard (low energy, Le) or approximately standard (high energy, He) amounts. Similar Le and He groups were established with cows on lowprotein $(\mathrm{Lp})$ concentrate with $12.5 \% \mathrm{DCP}$.

\section{Management}

The daily concentrate allowance was $3 \mathrm{~kg}$ before calving, this amount being increased soon after calving to levels which differed for the Le and He groups. From the third week of lactation, allowances were related to milk yield according to a schedule which aimed at underfeeding as regards energy in the Le groups, relative to standard. In year 1 , the cows being fed $\mathrm{He}$ rations received $3 \mathrm{~kg}$ more concentrates per day at a given milk yield. In year 2 , the amount of concentrates offered was decreased to emphasize the metabolic stress caused by low energy feeding. The He cows received $3.5 \mathrm{~kg}$ more concentrate than Le cows giving the same daily yields. Average values and ranges for estimated energy balances in year 1 and 2 are in Table 1.

Individual feed consumption was recorded daily, and milk yields 3 days a week. Grass silage analyses were performed monthly on pooled samples taken at 2 -week intervals.

\section{Clinical mastitls and ketosis}

Calvings were scattered over a long period 
from early September to the beginning of April. Cows treated for mastitis were given a single intramuscular injection of benzyl procaine penicillin (BP) $20 \mathrm{mg} / \mathrm{kg}$ and dihydrostreptomycin (DHS) $25 \mathrm{mg} / \mathrm{kg}$ followed by intrammary infusion of $500 \mathrm{mg} \mathrm{BP}$ and $1 \mathrm{~g}$ DHS into affected quarters for 3-4 days. A total of 15 cows were treated for clinical mastitis during the 2 years.

In the first year, only 1 cow received ketosis treatment ( 39 days after calving). In the second year, 7 of the 21 multiparous cows had to be treated for ketosis. Details of case histories and treatment are given by Ropstad et al. (1989).

\section{Sampling}

Blood samples were collected from the jugular vein at 6 a.m. (before morning feeding). Samples for estimation of immunologic parameters were collected 4 weeks prior to expected calving and 2, 4 and 8 weeks after calving. Samples for estimation of biochemical parameters were collected twice weekly from 2 weeks prior to expected calving to 12 weeks after calving. Analysis of heparinized whole blood samples (lymphocyte transformation tests) was performed within 6-9 h of sampling. Pooled milk samples were collected by milkoscope on the day of parturition and 2, 4 and 8 weeks after calving.

\section{Biochemical analyses}

The analyses were performed at the Department of Biochemistry, Norwegian College of Veterinary Medicine. Plasma acetoacetate (ACAC), glucose (GLUC), aspartate aminotransferase (ASAT), glutamate dehydrogenase (GLDH), sorbitol dehydrogenase (SDH), free fatty acids (FFA), total cholesterol (CHOL) bilirubin (BILI) and bile acids (BA) were determined as described by Ropstad et al. (1989).

For the present study, only samples collec- ted in the 2 nd, 4 th and 8 th week after calving were used.

\section{Immunologic analyses}

Lymphocyte responses to the mitogens phytohemagglutinin (PHA), pokeweed mitogen (PWM) and concanavalin-A (CON-A) were assayed according to the method described for the whole blood transformation test (Larsen 1979). The final concentrations of the mitogens used were $10 \mu \mathrm{g} \mathrm{PHA} / \mathrm{ml}, 50$ $\mu \mathrm{g} \mathrm{PWM} / \mathrm{ml}$ and $10 \mu \mathrm{g} \mathrm{CON}-\mathrm{A} / \mathrm{ml}$. The lymphocyte response is expressed as (mean counts per min of stimulated culture) ${ }^{1 / 2}$ (mean counts per min of control cultures) ${ }^{1 / 2}$. Observations with control values $>7000$ $\mathrm{cpm}$ were discarded from the data set, which resulted in $73 \%$ of the observations concerning lymphocyte responses remaining to be studied. The discarded observations seemed to be evenly distributed among the other observations.

Serum IgG (S-IgG) and milk IgG (M-IgG) concentrations were measured using a conventional single radial immunodiffusion test (Mancini et al. 1965). Commercial antiserum against cattle IgG produced in rabbits was used (Cappel Laboratories, USA). Precipitation zone diameter was measured by a "measuring viewer" (Behringwerke, W. Germany), and $\mathrm{mg} \mathrm{IgG} / \mathrm{ml}$ was calculated from a standard curve derived from five dilutions of purified IgG (Cappel Laboratories, USA) on each plate.

\section{Blood and milk cells}

The number of white blood cells in whole blood (WBC) was determined by electronic counting (Coulter Counter). Milk somatic cell count (MSC) was analysed by an automatic analyser (Fossomatic 360) from Foss Electrics, Denmark. 


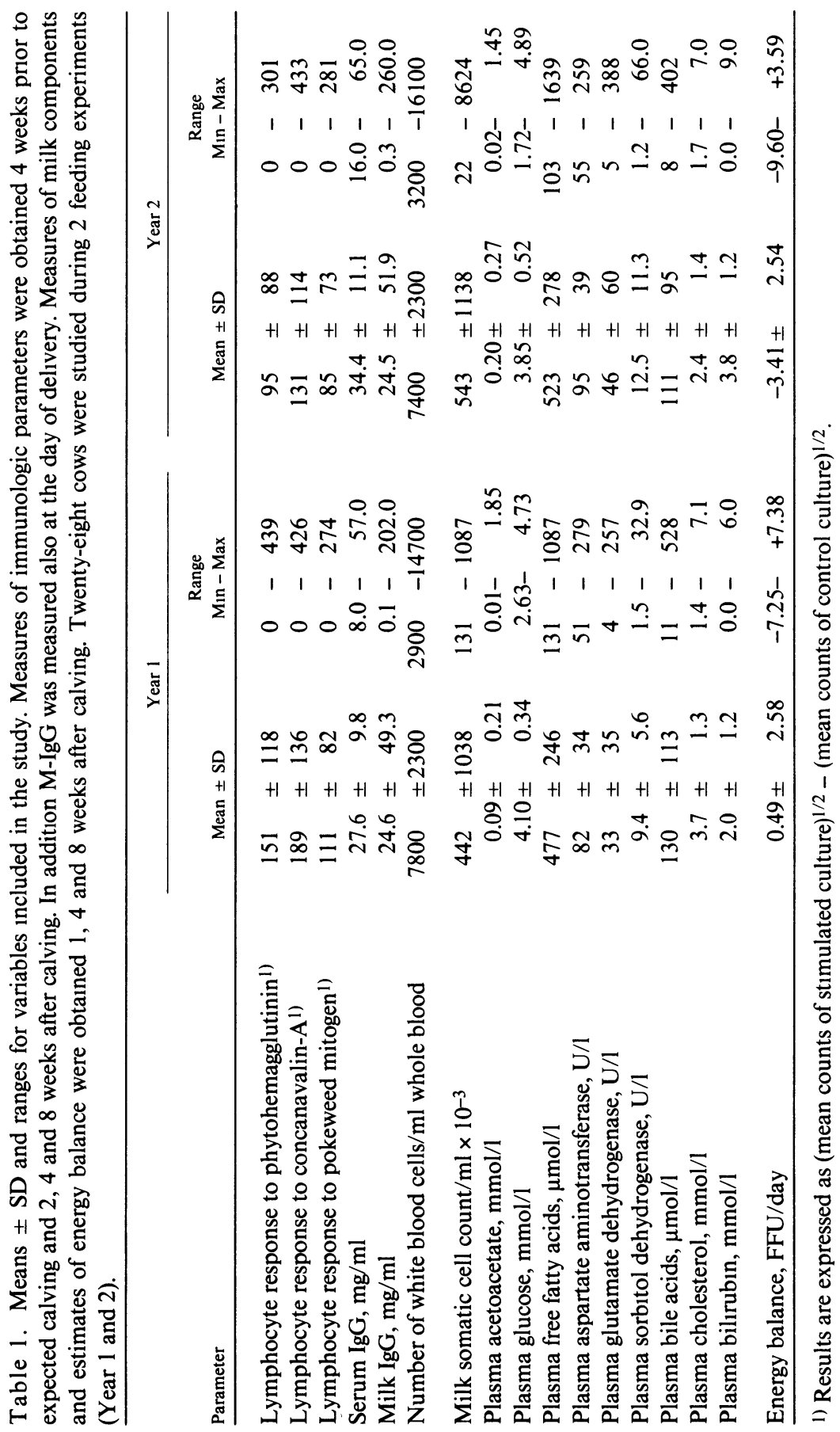




\section{Statıstıcal analysıs}

Differences between means were assessed using the Wilcoxon two sample test. The data from samples collected after calving were analysed by linear models (The GLMprocedure) from the Statistical Analysis System ( $S A S$ 1982). The immunologic parameters (PHA, CON-A, PWM, IgG-S, IgG-M and $\mathrm{WBC}$ ) were regarded as a function of the following independent variables: Cow, year, stage after calving, milk somatic cell count, and metabolic condition indicated either by energy balance (EB) or by the levels of separate plasma constituents (ACAC, GLUC, FFA, CHOL, SDH, GLDH, ASAT, BA). Possible interactions were included in the model and tested for significance. The variance contribution was calculated for each independent variable from 100 times its type III sum of squares (SS III) divided by total SS. Correlation analysis (Spearman correlation coefficient, $r_{s}$ ) was used to assess relationships between selected parameters. Significance tests for the differences between correlation coefficients were performed according to Snedecor (1959).

\section{Results}

\section{Means and ranges for included variables}

The mean values ( \pm SD) and ranges for the variables included are shown in Table 1. The mean energy balances were postive in year 1 and negative in year 2. ACAC mean value $( \pm \mathrm{SD})$ was $0.20 \pm 0.27 \mathrm{mmol} / 1$ in year 2 , compared with $0.09 \pm 0.27 \mathrm{mmol} / \mathrm{l}$ in year 1 . The corresponding averages for glucose were $3.85 \pm 0.52$ and $4.10 \pm 0.34$ $\mathrm{mmol} / \mathrm{l}$, respectively. Average lymphocyte responses to mitogens were lower in year 2 than in year 1 (Fig. 1, Table 1). The coefficients of correlation between ACAC and the energy balance (EB) were $r_{s}=-0.28(p<$ $0.01)$ and $r_{s}=-0.19(p<0.01)$ in year 1 and 2 , respectively.

\section{Effect of stage of lactation}

As shown in Figs. 1 and 2, there was an increase in both the mean lymphocyte response to mitogens and the mean S-IgG concentration from two to eight weeks after calving. However, the analysis of variance revealed that the effect of stage of lactation was significant only for the lymphocyte response to PHA ( $p<0.01$, Table 2). Mean M-IgG concentration decreased from about $100 \mathrm{mg} / \mathrm{ml}$ at calving to about $0.75 \mathrm{mg} / \mathrm{ml} 8$ weeks after calving, giving a variance contribution from sampling time of $64.1 \%(p<0.001$, Table 2).

\section{Effect of metabolic condition and energy balance}

There was a significant positive relationship between energy balance and lymphocyte response to mitogens (Table 2), which was not influenced by the exclusion of samples collected after ketosis treatment. No significant inter-relationships were observed when energy balance (see Table 2) was substituted by the plasma constituents listed in Table 1 . However, in both years there was a negative total correlation between S-IgG and GLDH $\left(r_{s}=-0.36\right.$, n.s. and $r_{s}=-0.45, p<0.05$ in year 1 and 2, respectively) and between M-IgG and CHOL $\left(r_{s}=-0.31\right.$, n.s. and $r_{s}=$ $-0.49, \mathrm{p}<0.05$, respectively).

In Figs. 1 and 3, the mean values of observations from cows which received ketosis treatment are shown separately. Treated cows showed lover mean lymphocyte responses to PHA and CON-A, and lower mean levels of WBC, during and after the treatment period. However, the differences illustrated were not significant except for WBC at 8 weeks after calving $(\mathrm{p}<0.05)$.

Effect of milk somatic cell count (MSC)

Increasing of MSC was associated with a decrease in the lymphocyte response to mi- 

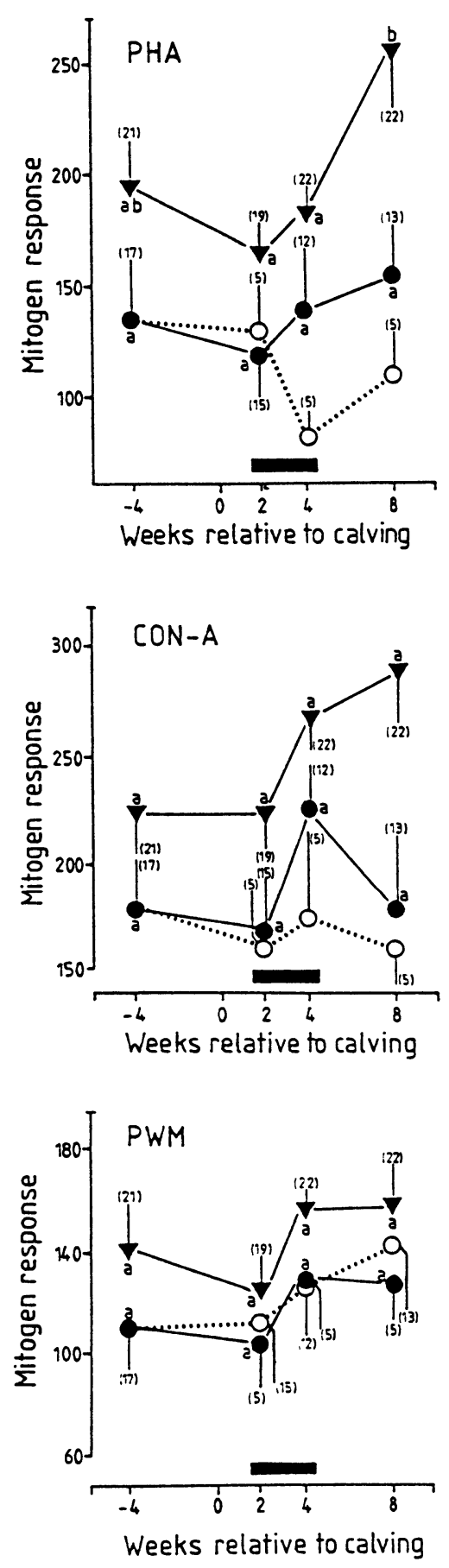

togens. The variance contribution from MSC on the lymphocyte responses to PHA, PWM and CON-A was $3.9 \%(\mathrm{p}<0.05)$, $3.6 \%(\mathrm{p}<0.05)$ and $2.9 \%(\mathrm{p}<0.06)$, respectively (Table 2 ).

\section{Effect of cow and year}

The variance contribution from the animal factor (COW) was significant for S-IgG, WBS and the lymphocyte response to PHA and CON-A (Table 2). Only S-IgG was significantly influenced by the effect of year (Table 2).

\section{Correlatıons between immune parameters}

At eight weeks after calving, there was significant correlation between the lymphocyte response to PHA on the one hand and the lymphocyte response to PWM and CON-A and the number of WBC on the other $\left(r_{s}=\right.$ $0.52, \mathrm{p}<0.001, \mathrm{r}_{\mathrm{s}}=0.85, \mathrm{p}<0.001$ and $\mathrm{r}_{\mathrm{s}}$ $=0.55, \mathrm{p}<0.001$, respectively) and similarly, between the lymphocyte response to CON-a on the one hand and the lymphocyte response to PWM and the number of WBC

Figure 1. Mean levels of lymphocyte responses to the mitogens phytohemagglutınin (PHA), concanavalin A (CONA) and pokeweed mitogen (PWM) related to time distance from calving. Results are expressed as: (Mean counts of stimulated culture $)^{1 / 2}-(\text { mean counts of control culture })^{1 / 2}$. Year $1(\nabla-\nabla)$ and $2(\longrightarrow)$ are shown separately. Observations from cows which were treated for ketosis with glucocorticords are shown separately for the second year $(\mathrm{O} \ldots \ldots)$. The treatment period is indicated by the horizontal black bars ( ). Numbers in parantheses give the no. of observations. Standard errors are ind1cated by vertical bars.

ab: Means within year differ significantly $(\mathrm{p}<$ 0.05). 
Table 2. Analysis of variance, linear models. Immune parameters as a function of the animal factor (COW), the year of study ( 1 or 2), stage after calving ( $0,2,4$ and 8 weeks), energy balance (EB) and milk somatic cell count (MSC). M-IgG was the only dependent variable measured on the day of delivery $(\mathrm{STAGE}=0)$.

\begin{tabular}{|c|c|c|c|c|c|c|}
\hline \multirow[b]{3}{*}{ Dependent variables I) } & \multicolumn{6}{|c|}{ Percentage of total sum of squares 1 ) } \\
\hline & \multicolumn{5}{|c|}{ Partial effects2) } & \multirow[b]{2}{*}{ Model } \\
\hline & cow & YEAR & STAGE & EB & MSC & \\
\hline Lymphocyte response to phytohemagglutının & $38.4^{\mathrm{a}}$ & $0.0^{\mathrm{ns}}$ & $6.4^{\mathrm{b}}$ & $5.6^{b}$ & $3.9^{\mathrm{a}}$ & $65.6^{c}$ \\
\hline Lymphocyte response to pokeweed mitogen & $30.3^{\text {ns }}$ & $0.1^{\mathrm{ns}}$ & $1.8^{\mathrm{ns}}$ & $4.3^{\mathrm{a}}$ & $3.6^{\mathrm{a}}$ & $48.9^{\text {ns }}(p=009)$ \\
\hline Lymphocyte response to concanavalin-A & $36.5^{\mathrm{a}}$ & $0.0^{\mathrm{ns}}$ & $2.6^{\mathrm{ns}}$ & $6.0^{\mathrm{b}}$ & $2.9^{\mathrm{a}}$ & $59.1^{\mathrm{b}}$ \\
\hline Serum immunoglobulin-G concentration & $40.7^{c}$ & $2.4^{\mathrm{b}}$ & $2.1^{\mathrm{a}}$ & $0.3^{\text {ns }}$ & $0.5^{\mathrm{ns}}$ & $69.9^{c}$ \\
\hline Milk ımmunoglobulın-G concentration & $5.4^{\mathrm{ns}}$ & $0.0^{\mathrm{ns}}$ & $61.5^{\mathrm{c}}$ & $0.0^{\mathrm{ns}}$ & $0.0^{\mathrm{ns}}$ & $80.3^{c}$ \\
\hline Number of white blood cells in whole blood & $60.3^{c}$ & $0.9^{\text {ns }}$ & $0.1^{\mathrm{ns}}$ & $0.0^{\mathrm{ns}}$ & $0.0^{\mathrm{ns}}$ & $63.3^{\mathrm{c}}$ \\
\hline
\end{tabular}

1) Level of significance: a) $\mathrm{p}<0.06$, b) p $<0.01$, c) p $<0.001$, ns) not significant

2) (Variable sum of squares type III/total sum of squares) $\times 100$; by $S A S$ (1982): Proc GLM
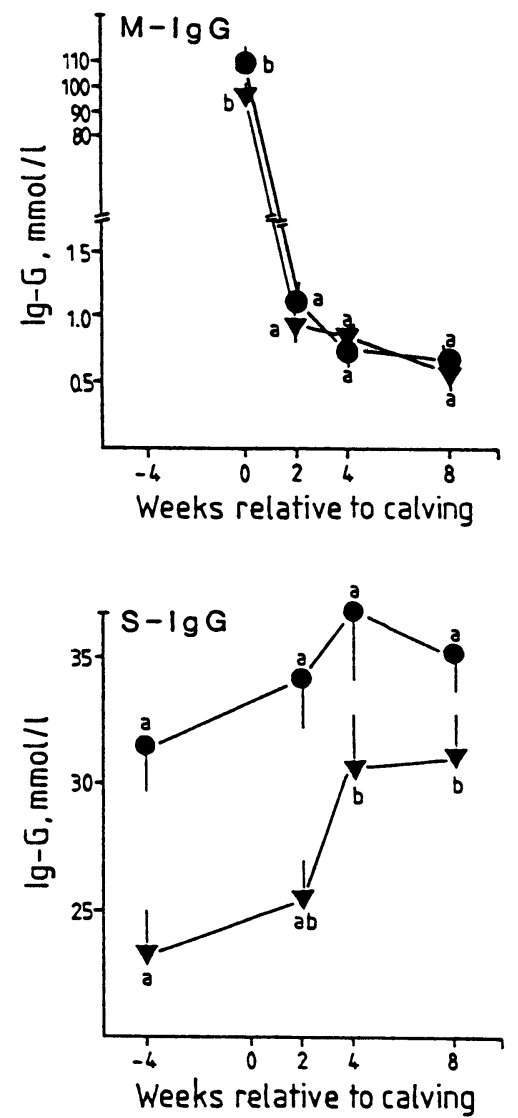

on the other $\left(r_{s}=0.46, p<0.01\right.$ and $r_{s}=$ $0.60, \mathrm{p}<0.001$, respectively). S-IgG and $\mathrm{M}-\mathrm{IgG}$ were not significantly correlated with any other parameters at this stage. The coefficient of correlation between the lymphocyte responses to PHA and CON-A increased from $r_{s}=0.39$ at 2 weeks after calving to $r_{s}=0.85$ at 8 weeks after calving, the increase being significant at $p<0.01$. The same trend was found for the correlation between the lymphocyte response to CON-A and PWM, though the differences observed were not significant.

Figure 2. Mean levels of immunoglobulin $G$ in milk (M-IgG) and serum (S-IgG) related to time distance (weeks) from calving. Year $1(\boldsymbol{\nabla}-\nabla)$ and $2(\longrightarrow)$ are shown separately. Vertical bars represent standard errors. 28 cows were sampled each year.

$a b$ : Means within year with different superscript differ significantly. 


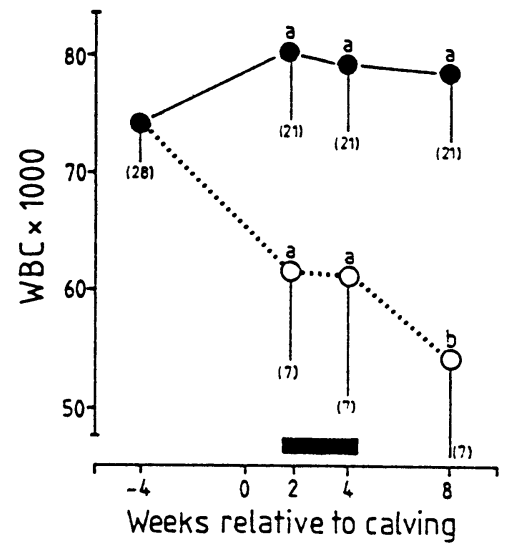

Figure 3. Mean levels of white blood cells (WBC) in whole blood in cows which were treated for ketosis with glucocorticoids $(\mathrm{O} \ldots \ldots)$ and untreated cows (-@) in the second year. Numbers in parantheses represent the no. of observations. The treatment period is indicated by the horizontal black bar (

ab: Means within week from calving with different superscript differ significantly $(\mathrm{p}<0.05)$.

\section{Discussion}

In the present study, we found a positive relationship between energy balance and the lymphocyte response to mitogens. This agrees well with reports from humans (Sheffy \& Williams 1982, Chandra \& Chandra 1986). In general, the severity of the impaired immunological response parallels the severity of the protein or calory nutritional deficiency (Sheffy \& Williams 1982). It is therefore likely that the energy feeding deficit which was obtained in year 2 would explain the lower average lymphocyte response to mitogens seen that year compared with year 1 (Fig. 1).

In an earlier in vitro experiment with separated bovine lymphocytes, Targowski \& Klucinski (1983) found that the mitogenic response to PHA was reduced when the lymphocytes were preincubated for two hours or longer with $\beta$-hydroxybutyrate or acetoacetate. The lack of significant relationships between plasma indicators of metabolic condition and immune functions may be due to the fact that these parameters showed relatively low coefficients of correlation to the energy balance.

Reld et al. (1983) investigated the relationship between liver fat content and various aspects of the immune response of cows soon after calving, and found that fatty liver was associated with leucopenia. In addition, the ability to mobilize leucocytes in response to an in vivo challenge appeared to be significantly impaired in cows with high levels ( $>20 \%$ ) of liver fat. The results of the present study cannot, however, be compared to those of Reld et al (1983) since the liver fat levels (measured in the fourth week of lactation) were very low (Ropstad et al. 1989).

Although the variance contribution was low, there was a significant relationship between the levels of MSC on the one hand and the lymphocyte responses to PHA and CON-A and S-IgG levels of the other. The negative relationship between mitogenic response and MSC may imply that in vivo lymphocyte function is compromised during mastitis. This would agree well with the results by Nonnecke \& Harp (1985) who found that milk lymphocytes from infected glands were essentially unresponsive to CON-A, PHA and PWM. Peripheral blood lymphocytes from cows with infected quarters responded less to PWM compared with peripheral blood lymphocytes from control cows.

The significance of the observed inter-relationships between MSC and mitogenic responses in the development of chronic mastitis remains to be studied using other assays for immune functions which are more relevant for immune protection against udder infections. Decreased mitogenic response 
1s not necessarily an expression of decreased resistance to udder infection.

In an earlier study, Yang et al. (1980) reported that both the percentage and the absolute numbers of peripheral blood B-lymphocytes were significantly lower in cows with mastitis, suggesting a possible effect of mastitis on humoral immunity. Our results did not support this finding sine no significant relationship was observed between S-IgG and MSC (Table 2).

The effect of time distance from calving (STAGE) was significant only for PHA and M-IgG, though, as shown in Figs. 1 and 2, the mean values of CON-A (Year 1), PWM and S-IgG also increased from two to eight weeks after calving. Wells et al (1977) found that lymphocytes from newly-calved cows apparently responded less to phytohemagglutinin than lymphocytes from non-pregnant cows. Similar findings have also been described in ewes (Burrels et al. 1978), bitches (Lloyd et al. 1983) and women ( $\mathrm{Ya}$ mamoto et al 1980). However, this alteration in immune reactivity is not universal and Mlyasaka \& McCullagh (1981) reported that peripheral blood lymphocytes collected from pregnant ewes showed constant proliferative reactivity to $\mathrm{CON}-\mathrm{A}$, and constant mixed lymphocyte reaction. Bırkeland \& Kristoffersen (1980) found in women towards the end of pregnancy no changes in the lymphocyte responses to PHA and PWM, while responses to CON-A were elevated. However, the lymphocyte response to specific antigens was least towards the end of pregnancy, increasing again after partur1tion.

The fact that the coefficient of correlation between PHA and CON-A increased significantly from 2 to 8 weeks after calving could possibly be a result of selective depression of the reactivity of lymphocyte subpopulations around parturition.
Our results provide some evidence that immune function in cows which received treatment for ketosis was reduced (Figs. 1 and 3 ). The lack of significant correlations between acetoacetate and immune parameters supports the notion that this effect is caused by ketosis treatment rather than metabolic status itself. There is evidence in the literature that glucocorticoids alter host defence mechanisms (Mulcahy \& Quinn 1986). Results obtained in cattle indicate that cortisol causes a decrease in lymphocyte response to mitogens (Roth 1985). The effect of glucocorticolds on WBC is more uncertain (Roth 1985). Cortisol has been reported to cause neutrophilia and eosinopenia, with no consistent effect on lymphocytes (Roth 1985). However, in both humans and cattle, a depletion in the number of circulating lymphocytes has been found after glucocorticosteroid treatment (Parllo \& Faucl 1979, Bloom et al 1979).

In conclusion, a significant positive relationship was observed between energy balance and lymphocyte response to mitogens. In further studies to evaluate the effect of energy restriction on immune function, we would prefer to perform immunological analyses more often, and test, not only, nonspecific immune response, but also specific antibody production and cell-mediated immunity to different antigens.

\section{Acknowledgements}

We wish to thank L. Midthjell, E. B. Gondrosen, L.-W. Fredriksen, H. Hansen and B. Johansen for excellent technical assistance. The experiment was financially supported by grants from The Norwegian Agricultural Research Council.

\section{References}

Birkeland SA, Kristoffersen $K$ Lymphocyte transformation with mitogens and antigens during normal human pregnancy: a longitudinal study. Scand. J. Immunol. 1980, 11, 321-325. 
Bloom JC, Kenyon SJ, Gabuzda TG Glucocort1cold effects on peripheral blood lymphocytes in cows infected with bovine leukemia virus. Blood 1979, 53, 899-912.

Burrells $C$, Wells $P W$, Sutherland AS Reactivity of ovıne lymphocytes to phytohaemagglutinin and pokeweed mitogen durıng pregnancy and in the immediate post-parturient period. Clin. exp. Immunol. 1978, 33, 410-415.

Chandra S, Chandra RK Nutrition, immune response, and outcome. Progr. Food Nutrit. Sc1. $1986,10,1-65$.

Grohn $Y$, Lindberg $L-A$, Bruss $M L$, Farver TB Fatty infiltration of liver in spontaneously ketotic dairy cows. J. Dairy Sc1. 1983, 66, 2320 -2328 .

Larsen HJ A whole blood method for measurnng mitogen-induced transformation of sheep lymphocytes. Res. Vet Sc1. 1979, 27, 334-338.

Lloyd SS. Immunosuppression during pregnancy and lactation. Irish vet. J. 1983, 37, 64-70.

Lloyd S, Amerasinghe PH, Soulsby EJL- Periparturient immunosuppression in the bitch and its influence on infection with Toxacara canis. J. small Anım. Pract. 1983, 24, 237-247.

Mancinı G, Carbonara A, Heremans JF Immunochemical quantitation of antigens by single radial immunodiffusion. Immunochemistry 1965, 2, 235-254.

Miyasaka $M$, McCullagh $P$ Immunological responsiveness of maternal and foetal lymphocytes during normal pregnancy in the ewe. $J$. reprod. Immunol. 1981, 2, 15-27.

Mulcahy $G, Q u i n n$ PJ A review of immunomodulators and their application in veterinary medicine. J. vet. Pharmacol. Therap. 1986, 9 , 119-139.

Nonnecke BJ, Harp SA Effects of chronic staphylococcal mastitis on mitogenıc responses of bovıne lymphocytes. J. Dairy Scı. 1985, 68, 3323-3328.

Parllo JE, Faucl AS. Mechanisms of glucocorticoid action on immune processes. Ann. Rev. Pharmacol. Toxicol. 1979, 19, 179-201.

Reld IM, Collins RA, Dew AM, Hill AW, Willtams $M R$. Immune competence of dairy cows with fatty liver. Proc. 5th Internat. Conference on Production Disease in Farm Animals. Uppsala 1983, p. 191-194.
Ropstad E, Halse $K$, Refsdal AO Variations in parameters of liver function and plasma progesterone related to underfeeding and ketosis in a dairy herd. Acta vet. scand. 1989, 30, 185197.

Roth $J A$ Cortisol as mediator of stress-associated 1mmunosuppression in cattle. In G. P. Moberg: Animal Stress. American Physiological Society, Maryland 1985, p. 225-243.

Saarınen P, Shaw JC Studies on ketosis in darry cattle. XIII. Lipids and ascorbic acid in liver and adrenals of cows with spontaneous and fastıng ketosis. J. Dairy Sc1. 1950, 33, 515525.

SAS (Statistical Analysis System) SAS User's Guide: Statistics. SAS Institute Inc., Cary, N. C. 1982.

Sheffy BE, Willams AJ Nutrition and the 1mmune response. J. Amer. vet. med. Ass. 1982, 180, 1073-1076.

Snedecor $G W$ Statistical Methods. Iowa State college Press. Ames, Iowa 1959, 434 pp.

Targowsk $S P$, Klucinskl $W \cdot$ Reduction in mitogenic response of bovine lymphocytes by ketone bodies. Amer. J. vet. Res. 1983, 44, 828830.

Wells $P W$, Burrells $C$, Martın WB Reduced m1togenic responses in cultures of lymphocytes from newly calved cows. Clın. exp. Immunol. 1977, 29, 159-161.

Yamamoto T, Hirata H, Tanıguchı H, Kawal Y, Vematsu A, Sugiyama $Y$ Lymphocyte transformation during pregnancy. An analysis using whole blood culture. Obstet. Gynec. 1980, 55, 215-219.

Yang TJ, Jantzen-Abo PA, Williams LF Depression of $\beta$-lymphocyte levels in the peripheral blood of cows with mastitis. Infect. Immun. 1980, 27, 90-93.

\section{Sammendrag}

Immunfunksjon hos melkeku relater tll energl balanse og stoffskiftettlstand $\mathrm{l}$ tidlig laktasjon

To fôringsforsøk ble gjennomført i 2 påfølgende år med 28 NRF-kyr i hvert forsøk. Kyrne ble fordelt tilfeldig på 4 fôringsgrupper fra 4 uker før forventet kalving til 12 uker etter kalving. Forsøksopplegget var faktorielt $(2 \times 2)$ med hensyn til protein- 
innhold i kraftforret (henholdsvis 17,5 \% fordøyelig råproteın (DCP) og 12,5 \% DCP) og kraftfôrmengde (henholdsvis normfôring og underfôrıng). Sılo ble gitt etter appetitt.

Prøver for bestemmelse av følgende immunparametre ble tatt 4 uker før forventet kalving og 2, 4 og 8 uker etter kalvıng: Immunoglobulın-G 1 serum og melk (ved kalving og 2, 4 og 8 uker etter kalving), antall hvite blodlegemer og lymfocyttrespons til mitogenene phytohemagglutinın, concanavalın-A og pokeweed mitogen.

Ved variansanalyse ble immunparametrene betraktet som en funksjon av: ındivid, forsøksår, avstand fra kalving, stoffskiftestatus indikert enten ved energibalanse eller ulike plasmakomponenter og jurhelse indikert ved celletal i melk.

Det ble funnet en signifikant positiv sammenheng mellom energibalanse og lymfocyttrespons på mitogener. Det var få holdepunkter for signifikante sammenhenger mellom immunparametre og plasma indıkatorer på stoffskiftetılstand. Lymfocyttresponsen på phytohemagglutinin og nivåene av ımmunoglobulın-G i serum økte fra kalving tıl 8 uker etter kalving. Effekten av forsøksår var sıgn1fikant for nıvåene av immunoglobulin-G i serum. Høye celletall i melk var forbundet med en signifikant redusert lymfocyttrespons på mitogener.

(Recelved March 23, 1988; accepted August 18, 1988)

Reprints may be requested from: Erik Ropstad, Norwegian College of Veterinary Medicıne, P. O. Box 8146 Dep., N-0033 Oslo 1, Norway. 
